1. 走查線数, 2. 走査方式, 3. 走查周波数, 4. アス ペクト比, 5. 入力映像信号, 6. 入力インピーダンス, 7. CRT, 8. 有効画面サイズ, 9. 解像度 (中心), 10. 映 像帯域巾, 11. 偏向ひずみ(歪), 12.X線漏れ線量, 13 . 電撃に対する保護の形式と程度，14. 保護接地回路の抵 抗，15. 接地漏れ電流，16. 外装漏れ電流，17. 耐電圧, 18. 電源条件，19. 使用環境条件，20．保存環境条件, 21. 外形寸法及び重量

(細矢志郎)

\section{CT の標準化班（SC-4209）}

$\mathrm{SC}-4209$ 委員会の今年度の主な活動は, IEC 文書 $\{62 \mathrm{~B}$ (S) 148\}ににたいするコメントの作成と骨塩測定用ファン トムの標準化について検討を行っている.

CT 装置による骨塩定量検查の薬価申請に関し, 平成 5 年更新に向け骨塩定量ファントムの規格化が急務とさ れこれを検討してきた. 薬価としては, CT 検査に骨塩 測定を付加するか, 単独検査となるか法, 今後の厚生省 の判断による. 当委員会では, CT 装置用の骨塩測定用フ アントムの規格評準化を進めていくことで合意された。

〈骨塩測定用ファントムの現在の状沉〉

国内では，中外製薬製の B-MAS ファントムが多勢を しめている，その他各メーカー独自のファントムがある (主に外国メーカー)，ファントムの成分としては，炭酸 カルシウム $\left(\mathrm{CaCO}_{3}\right)$ からハイドロキシアパタイト $\{\mathrm{Ca}$ $\left.\left(\mathrm{PO}_{4}\right)_{6}(\mathrm{OH})_{2}\right\}$ におきかわってきている。 〈問題点〉

$\mathrm{X}$ 線 CT 装置間により得られる值が変化する，測定値 は，被写体寸法などにより值がことなる。被写体とファ ントムの間に隙間が生じると值が変化する，アーチファ クトによる誤差が生じるなどがあげられる。

ファントムのロッド成分の精度は CT 值で $2 \sim 3$ 程度 ある。

〈現状及び今後の進め方〉

骨代謝学会及び骨代謝 WG のメンバーの協力を得て 臨床データの収集および意見を参考とする。

骨塩測定用の校正用ファントムとして，ESP（European Standard Phantom）校正用ファントムが欧州で 検討されている.

骨塩測定用ファントムと同時に校正用ファントムの検 討が必要と思われ，これらのことをもとに，ファントム の規格標準化について検討を行っている。

ファントムの形状，寸法，材質を含め標準化に必要な 項目について各委員が持ちかえりまとめていくことで, 今後進めていく.
附 現状の保険点数

骨塩定量検查（DEXA の場合）

全身の場合 400 点

一部位の場合 200 点

（北村善明）

\section{核医学機器班（SC-4401）}

今年度も委員会をほほ毎月開催した。主な活動内容は (1) JESRA X-71 (ガンマカメラ安全性の保守点検基準) の総仕上げ, (2) NEMA 文献の調査, (3) JESRA X-51(ガ ンマカメラの性能測定法と表示法) の改正原案作成準備 である。

1. ガンマカメラ安全性の保守点検基準

この規格を，JIRA 会報の124号（1992年 7 月発行）に て JESRA X71とし公開した。これは既に公開（JIRA 会 報121号，1991年 1月発行）済みの JESRA X67（ガンマ カメラ検出部性能の保守点検基準）と 1 対の, 他の一方 である. 単結晶型ガンマカメラの保守点検基準に関して はこれにて, 検出部性能と安全性との両方の基準が出揃 った.

この両規格はいづれも JESRA（日本放射線機器工業 会）規格であるものの，そのタイトルが示す如く内容的 に保守点検基準であるため，使用者側と極めて関係深い. この両規格は, 単結晶型ガンマカメラの JIS 化を目的の 一段階とし行われたものであり，これにて当装置 JIS 化 への前処理作業はひと先づ終了した。

\section{NEMA 文書の調查}

NEMA 勧告 (Performance measurement of scintillation cameras）1986年の改正版は，下記本文・付録の 総数43ページから成っている.

Section 1 Reference publication and definitions

Section 2 Single crystal scintillation camera test methods

Section 3 Multiple crystal scintillation camera test methods

Section 4. Scintillation camera based single photon emission computed tomography (SPECT) performance measurement standards

Section 5 Traceability data

Section 6 Traceability data (multicrystal cameras)

Appendix A Rationale for single crystal scintillation camera

Appendix B Rationale for multiple scintillation crystal camera 
Appendix C Rational for scintillation camera based single photon (SPECT) performance measurement standards

Appendix D SPECT system performance measurement reporting form

Appendix E Reconstructed (relative image noise) image uniformity

Appendix F Collimator sensitivity Calibration note

このうち今年度の作業計画と最も関係深い部分は単結 晶型ガンマカメラであるため, Section 2 と 4 並びに Appendix Cにつき各委員が分担して和訳した。その後 これを用いて1985年制定の JESRA X-51（ガンマカメラ の性能測定法と表示法）と対比し，両者の類似点・相違 点対比表を作成した。現在この対比表は JESRA X-51改 正原案作成の基礎資料とし活用中であり，その他の部分 についても必要に応じ遂次和訳．改編し利用の予定であ る.

3. ガンマカメラの性能測定法と表示法

委員会の長期展望とし，この規格を JESRA から JIS へと格上げする点では一致している．従ってその前段階 とし, 前述の保守点検基準も制定された。しかしここの 規格自体の内容が極めて多いこと, 角型検出器や断層可 能型装置及び関連規格の NEMA 規格等への配慮も必要 であること等の背景もあり，現段階ではその改正に今し ばらく期日を要する，そこで先づ改正案のタタキ台を作 ることとし，タタキ台作りは各委員が分担し昨年末より 執筆を開始した．従って改正原案作成作業はまだ緒につ いたばかりであり，全体的に見て今だ手つかずの部分が 少くないため，次年度継続作業の一つとなる予定である。

(星野光雄)

\section{MR の標準化班（SC-4402委員会）}

本来は, 安全や用語の標準化等を審議していたが, MR 装置の標準化に関する調查研究委員会が平成 2 年度に発 足したのに伴い，SC4402を拡大して，第 2 分科会を分担 することになった。平成 4 年度に調查研究会の動きが終 われば，本来の活動に戻る。

（山田和美）

\section{ポジトロン CT 班（SC-4405）}

工業会と本学会側委員との合同会議は, 昨年 8 月21日 より開催されはじめた。 工業会側委員のみでの会議はそ れ以前から関催されており，この日は通算第17回目であ った. それ以降は每月 1 回を原則に開催され，作業課題 は JESRA X -73 (PET 装置の性能評洒法) の草稿作成で ある。

この草稿の原典は, 日本アイソトープ協会医学・薬学 部会サイクロトロン核医学利用専門委員会/核医工学ワ ーキンググループの作成した「PET 装置の性能評価のた めの測定指針」であり，この指針作成に当っては当班工 業会側委員がオブザーバーとして参加し，当指針は昨年 8 月刊行された. つまり, 本学会側委員の出席開催時期 はこの指針の刊行時期と同じであり，観点を変えれば， 本学会側委員との合同会議は当指針の刊行を待って開始 されたと言える.この指針はその序言で, 米国(NEMA： PET の性能測定法) とヨーロッパ (EEC：PET 装置の性 能評価法)の規格を参考にし,できるだけ NEMA に準拠 し, かつ日本の事情を考慮し, PET 利用者がなるべく容 易に実施できるものとしてまとめた，と述べている．従 ってこの理念は, 当班の思想とよく一致する. 全体構成 は, 1. 適用範囲, 2. 用語の意味, 3. 一般的事項, 4. 性 能評価法の 4 群から成っており,そのうち3．の一般的事 項では(1)ファントム容器，(2)線源核種，(3)線源放射線の 測定と放射能減衰の補正，(4)測定上の注意事項が記載さ れ，また，4．の性能評価法には(1)空間分解能，(2)検出感 度，(3)散乱フラクション，(4)計数損失および偶発同時計 数, (5)画像濃度の均一性, (6)吸収・散乱補正の精度, (7) 高計数率特性（計数損失の補正の精度と $\mathrm{S} / \mathrm{N}$ 比), (8)部 分容積効果 (リカバリ係数)，が盛り込まれている.

この様に, JESRA X-73草稿の原典（指針）は, 全体 構成及び個々の夕イトルからみる限り体裁的には規格そ のものと極めて近い。しかし，この草稿は全文20余ぺー ジを通じ個及条項中の表現法までもが殆んど同じで，原 典の丸写しそのものだった。つまり規格とし利用するた めには，用語統一や表現法の簡潔化及び重複部分の一覧 表化など，更に推敲すべき部分が多かった，従って班作 業では各条項の意味を変更すること無く，より規格らし い表現法や体裁へと修正することに努力した。だが当指 針は，指針とし実現されたものであり委員会も解散して いること，1個所の表現法変更は全文修正に連動し量的 に大量であること，大幅修正に当っては原典作成委員会 の了解が必要であること，等の理由から大幅修正は不可 